\title{
Emotional Burden in Parents of Children with Trisomy 21: Descriptive Study in a Colombian Population
}

Cansancio emocional en padres de niños con trisomía 21: Estudio descriptivo en una población colombiana

Recibido: 08 de septiembre de 2014| Aceptado: 27 de mayo de 2015

\author{
SONIA JARAMILLO ** \\ Universitätsklinikum Ulm Innere Medizin III, Alemania \\ SOCORRO MORENO **** \\ VIVIANA RODRÍGUEZ*****
}

Pontificia Universidad Javeriana, Bogotá, Colombia

doi: 10.11144/Javeriana.upsy15-1.ebpc

Para citar este artículo: Jaramillo, S., Moreno, S., \& Rodríguez, V. (2016). Emotional Burden in Parents of Children with Trisomy 21: Descriptive Study in a Colombian Population. Propiedades psicométricas de la Escala de Ideología de Género en adolescentes colombianos. Universitas Psychologica, 14(1), 29-38. http://dx.doi.org/10.11144/Javeriana.upsy15-1.ebpc

* Artículo de investigación científica. Presenta una parte de los resultados de un proyecto llevado a cabo como trabajo de grado para recibir el título de magíster en epidemiologia clínica. El estudio se realizó con recursos propios del investigador.

***Correo electrónico: soniajaramillo85@gmail.com;

*** Correo electrónico: isabel.moreno@javeriana.edu. co

***** Correo electrónico: viviana.rodriguez@javeriana. edu.co

\begin{abstract}
A B S T R A C T
The role of a parent with a disabled child can be highly demanding. There are few publications concerning parental emotional exhaustion in Latin America. The present prevalent case-controlled study evaluated the frequency of emotional exhaustion in 103 parental couples of parents of children with Down Syndrome (DS); likewise the study explores the rate of emotionally exhausted and depressed mothers in comparison with the fathers. This outcome was measured using a modified and validated version of the Maslach Burnout Inventory. The results showed a prevalence of emotional exhaustion of $52.64 \%$. In the matched-pair analysis we found a higher chance of exhaustion in mothers in comparison with their partners. Keywords

Trisonomy 21, Emotional Burden, Parents

\section{RESUMEN}

El trabajo de un padre con un hijo con discapacidad puede llegar a ser muy exigente. Existen pocas publicaciones que hacen referencia al agotamiento emocional de los padres de niños con discapacidades en América Latina. El presente estudio de casos y controles prevalentes describe la frecuencia de agotamiento emocional en 103 parejas de padres de niños con síndrome de Down. También describe las diferencias en el agotamiento emocional y depresión entre padres y madres. Este resultado se midió usando una versión modificada y validada del Maslach Burnout Inventory. Los resultados mostraron una prevalencia de agotamiento emocional del 52,64\%. En el análisis apareado encontramos una mayor probabilidad de agotamiento en las madres en comparación con sus parejas.

Palabras clave

Trisnomía 21, Sobrecarga emocional, Padres
\end{abstract}




\section{Emotional Burden in Parents of Children with Trisomy 21:}

Descriptive Study in a Colombian Population

The frequency of Down syndrome (DS) in Colombia has been reported between 16.3 and 17.8 per 10,000 live births (Castilla \& Orioli, 2004; Zarante, Franco, López, \& Fernández, 2010), and the disorder ranks third in frequency among congenital malformations nationwide. Children with this genetic condition have not only a mental impairment but also other types of disabilities or malformations (Bull \& the Committee on Genetics, 2011). Since the 70s, it has been recognized that all these patients require close and strict care by another person, usually a parent (Nurse, 1977; Ryde-Brandt, 1988). The burden of taking care of a handicapped child seems to increase with having to give up one's job, the lack of social interaction, and the realization that the child's condition won't improve (Abbeduto et al., 2004; Dabrowska \& Pisula, 2010).

Some authors have suggested that motherhood, regardless the condition of the child, is a major risk factor for stress due the responsibilities in the care and education of the children (Akgün, 2014; Cameron, Dobson, \& Day, 1991). A recent meta-analysis suggested that parenting stress is higher in parents of children with autism spectrum disorders or DS than in parents of typically development children (Hayes \& Watson, 2013). Other studies have shown that the stress levels of mothers of children with DS are higher than those of mothers of non-disabled children (Esdaile, 2009; Lenhard, Breitenbach, Ebert, Schindelhauer-Deutscher, \& Henn, 2005). Quantitative cohort studies and quasi-experiments in Latin America found that the sensation of tiredness and high demand on the parents caused by taking care of the child with DS did not change in the time of the follow-up. Another important finding was the higher prevalence of exhaustion in mothers than in fathers (Pérez \& Baró, 2008; Van Der Veek, Kraaij, \& Garnefski, 2009). The findings of a study prublished in 2015 showed that life stress, burnout and depression are closly associated and could share some underling mechanisms (Plieger, Melchers, Montag, Meermann, \& Reuter, 2015). The depression and the emotional exhaustation are correlated with the number of life stress events (Plieger et al., 2015).

According to the description made by Procaccini and Kiefaber in 1983, parental burnout is a condition resulting from untreated chronic exhaustion due to the persisting demands of family needs and the cessationof non-parental activities, which deplete the energy and motivation of the parents (Procaccini \& Kiefaber, 1983), several studies have investigated the frequency and severity of presentation of the syndrome among parents of children with various pathologies including diabetes mellitus type-I, irritable bowel syndrome, and parents of survivors of central nervous system neoplasms (Lindström, Aman, \& Norberg, 2011; Norberg, 2010). Those studies showed an association between the parent's sex and the emotional exhaustion level. A recent study that compared the burnout among mothers of children with autism and mothers of children with hearing impairments, finding that the global frequency of the syndrome is $74.78 \%$ (the frequency in mothers with autistic children is $85.74 \%$; mothers with hearing-impaired children is $63.81 \%$; t: 7.07, p<0.001; Varghese \& Venkatesan, 2013), suggested that the difference in the impairment of the child could affect the level of burnout in parents.

The physical exhaustion level in parents of handicapped children has been related with the availability of social or professional support networks. Consequently, parents with strong social networks adapt better to their children's necessities and experience better family functionality and wellbeing (Cuskelly \& Gunn, 2006; Lam \& Mackenzie, 2002; Molina \& Agudelo, 2006).

The aim of this study was to determinate the rate of developing emotional exhaustion between mothers of DS children compared to that of their partner, taking into account the most relevant variables as sex, age, marital status, household income, occupational status, job schedule, education level, child age, child comorbidities, number of caregiv- 
ers, number of siblings, daily time spent with the child, coping strategies, and presence of depression.

\section{Method}

Design

A prevalent case-controlled study matched by family and nested in a cross-sectional study was conducted. This design was chosen because it allows for the estimation of the intra-couple difference, controlling for confounding variables (e.g., child comorbidities or household income).

\section{Participants}

The participants were parents of DS children who fulfilled the following criteria: age between 5 and 10 years old and only mild cognitive disability. The child's age range was selected because it is expected that by this period parents have already processed the grief of having a handicapped child and the child has had a neuropsychological assessment, has overcome the serious complications linked to the chromosomopathy, has not shown significant changes in his or her development trends, and has not started puberty. Parents of children with severe cognitive disability were excluded because of the much higher burden that this represents to them. Potential participants were contacted at fifteen organizations that support families with children who have cognitive disabilities, and at five schools for special education in Bogotá, Colombia and in two other nearby towns between October 2011 and February 2012. Additionally, to be enrolled, each parental couple had to meet the following criteria: both parents must agree to participate; both parents must be biological parents of the child; and neither parent could have a chronic disease, be a participant in another study, or take care of another handicapped person in addition to the child with DS.

The sample size was estimated using the formula proposed by Lachin (2008) based on the following parameters: type-I error of 0.05 , type-II error of 0.20 , case proportion of 0.45 , and OR of 2.0. The final sample size was 103 parental couples. We employed incidental sampling until we reached the sample size.

\section{Materials and Procedure}

\section{Coping strategies}

Coping strategies were measure using the "COPE scale" (Carver, Scheier, \& Weintraub, 1989). This scale has 60 items that assess a broad range of coping responses and uses a four-point scale for responses ( $1=\mathrm{I}$ usually don't do this at all; $2=\mathrm{I}$ usually do this a little bit; $3=\mathrm{I}$ usually do this a medium amount; $4=$ I usually do this a lot). The scale has shown adequate psychometric properties in multiple populations, including parents of chronically ill children.

\section{Depression.}

The presence of depression in parents was measured using the Whooley Depression Screen (Whooley, Avins, Miranda, \& Browner, 1997). This screening instrument has two questions that assess the main symptoms of depression in the past 30 days and use a dichotomic scale (yes/ no). This instrument has been recognized by the National Institute for Health and Care Excellence as an adequate screening instrument in general populations, with a reported sensibility of $95 \%$ and specificity of $66 \%$ (Pilling, Anderson, Goldberg, Meader, \& Taylor, 2009).

\section{Emotional Exhaustion.}

In the emotional exhaustion (EE) subscale, nine items with a seven-point scale $(0=$ Never; $1=A$ few times a year or less; $2=$ Once a month or less; $3=\mathrm{A}$ few times a month; $4=$ Once a week; $5=\mathrm{A}$ few times a week; $6=$ Every day) from the Maslach Burnout Inventory (MBI; Maslach, Jackson, \& Leiter, 1997), which was previously validated by Pelsma, Roland, Tollefson, \& Wigington (1989) was used to determine the presence of emotional exhaustion among the participant couples. A pa- 
rental couple was classified as having emotional exhaustion if he or she scored more than 19 on the EE subscale.

\section{Socio-demographic variables.}

Data on parents' age, marital status, household income, number of children, occupational status, job schedule, education level, child age, child comorbidities, number of co-caregivers, and daily time spent with the child were gathered using a survey that was designed for this study.

\section{Procedures}

The protocol was reviewed by the Universidad Javeriana Medical School Review Board. All participant organizations and schools reviewed a protocol summary and gave access to parents' information and permission to contact potential subjects. All participants signed an informed consent form developed according to the current guidelines for research in humans (Australian National Health and Medical Research Council, 1999).

A group of volunteers was trained in each participating institution to help individuals fill out the survey instruments. These assistants were responsible for the verification of the selection criteria, and they answered participants' questions.

\section{Results}

The statistical analyses were performed using STATA 12 software (StataCorp, 2011). We calculated the prevalence of emotional exhaustion among the couples (at least one of the parents fulfilled the criteria for the outcome), and then we separated them in two groups: one in which both parents fulfilled the criteria and the other where only one parent did. We also quantified the number of fathers and mothers with emotional exhaustion.

To estimate the odds that a mother or a father had developed emotional exhaustion in comparison with the other member of the parental couple, we generated a conditional (fixed-effects) logistic regression model that included all the variables that were independently collected for each member of the parental couple. We selected the final model using a backward elimination technique. Finally, using Cramer's V, we assessed the association between emotional exhaustion and depression among mothers and fathers independently.

We enrolled 103 parental couples that met our selection criteria. Table 1 shows the main participant characteristics. The average age of the DS children was 7.5 years (SD 1.9). Most prevalent comorbidities found among the children were cardiopathy (48.54\%), lung diseases (47.57\%), hypothyroidism (42.72\%), hypotonia (39.81\%), visual impairment (41.75\%), and hearing impairment (14.56\%). The only two significantly different variables between mothers and fathers were full-time jobs $(30.10 \%$ of mothers had full-time jobs, compared with $89.30 \%$ of fathers; $p$-value $<0.001$ ) and the time spent with the child per week (mothers spent significantly more time compared with fathers).

As shown in Figure 1, in the 44 families in which only one parent was emotionally exhausted, we observed that 38 of the exhaustion cases were the mother's and the other six were the father's. In 10 couples both parents had the condition. This amounted to a total of 54 of the 103 families fulfilling the criteria for emotional exhaustion, giving us a prevalence of $52.64 \%$.

In the conditional (fixed-effects) logistic regression model we found that the variable "occupational status" was the only significant variable in the model other than the sex of the parent. We found that mothers had almost four times the odds of developing emotional exhaustion, controlled by occupational status, in comparison with their partners $(\mathrm{OR}=3.6, \mathrm{CI} 95 \%$ [1.3 - 9.7]).

In the comparative analysis of demographic data we found a depression frequency of $36 \%$ in the group of exhausted mothers and $4 \%$ in non-exhausted mothers (CI95\% [17.4\% - 46.2\%] $\mathrm{p}<0.01)$. The frequency of depression was higher in mothers than in fathers: $18.5 \%$ vs. $8.7 \%$ (CI95\% [0.4\% - 19.0\%] $\mathrm{p}<0.05)$. In the case of the fathers, the amount of time spent with the child was significantly higher in exhausted fathers than in non-exhausted ones. Of the exhausted fathers, $62 \%$ spent between 36 to 
84 hours per week; this figure was $20 \%$ in the nonexhausted group (CI95\% [16.6\% - 67.0\%] $\mathrm{p}<0.01$ ).

To assess the correlation in the group of mothers between the presence of depression and the emotional exhaustion, we performed a Cramer's $V$ that showed a moderate correlation between these two variables $(\mathrm{V}=0.4$, CI95\% [0.23 - 0.56] $\mathrm{p}<0.001)$.

\section{Discussion}

The findings of this study suggest that mothers of children with DS have a higher likelihood of being exhausted than other parents. It is important to point out that the frequency of emotional exhaustion in the families with children with DS coincided with the frequency reported by several studies of families of children with cognitive disabilities (Lindström et al., 2011). The chance of a mother being emotionally exhausted is 3.6 times higher (IC 95\% 1.3 - 9.7) in comparison with that of her partner. Some studies have found that the frequency of emotional exhaustion in mothers was two times greater than in fathers (McGrath, Stransky, Cooley, \& Moeschler, 2011; Most, Fidler, Booth-LaForce, Laforce-Booth, \& Kelly, 2006); however, those studies did not consider the parental couple as a unit of analysis, as the present study did. In the logistic regression model, socio-demographic information, economic information, and information on the children's most relevant characteristics were included to find the actual difference between the emotional exhaustion of mothers and fathers. However, these rates are adjusted for occupational status. This finding suggests that having an occupation could be a relevant factor in the development of exhaustion symptoms.

The prevalence of emotional exhaustion in the studied families was $52.46 \%$. In $86.30 \%(n=44)$ of cases where only one parent was emotionally exhausted, the parent with this symptom was the mother. These findings are similar to reports of the prevalence of emotional exhaustion in mothers of children with autism and mothers of children with hearing impairments (Varghese \& Venkatesan, 2013). The findings of the present study suggest that the mothers of DS children should be prioritized over the fathers in coping programs and psychological therapies (Martínez Fontanilles \& Rodríguez Vernal, 2010; Sharav, Collins, \& Shlomo, 1985) and that mothers could benefit from engaging, in an occupation outside home, even a part-time job.

The prevalence of depression in the mothers was $18 \%$, which was higher than the one found in the fathers. In the subgroup analyses the mothers with emotional exhaustion had a higher frequency of depression than non-exhausted mothers did (36\% vs. $4 \%$ ). This is a novel finding in this population, but is consistent with findings that associate life stress events, depression, and burnout (Plieger et al., 2015). On the other hand, our prevalence of depression in mothers was similar to the one ascribed to the general female population in Colombia (Gómez-Restrepo et al., 2004). This finding was interesting because according to other studies the prevalence of depression in mothers of disabled children should be higher (Abbeduto et al., 2004; Martínez Fontanilles \& Rodríguez Vernal, 2010).

This study found a mild correlation between the presence of depression and emotional exhaustion in mothers, where the diagnosis of depression was more frequent in the affected group; this finding is similar to the correlation found by Plieger et al. (2015) that shows a moderate correlation between burnout and depression in samples of both healthy and depressed people $(\mathrm{r}=0.61$ and $\mathrm{r}=0.46$, respectively).

Despite its strengths, this study's limitations should be kept in mind. Only 28\% of families in this study had information about the severity of the disability of their children. Furthermore, only half of the children (48\%) had some kind of neuropsychological assessment. In absence of this variable we couldn't include the severity of the disability in our analysis. The matched-pairs design helps to reduce the confounding bias, but emotional exhaustion continues to be a subjective phenomenon.

In conclusion, this study showed that mothers of children with DS are more likely to be emotionally exhausted and depressed than their partners. Thus, efforts to prepare and educate them in effective 
coping strategies could modify the way they value the relationship with their children and generate a positive impact in the process of raising their children with DS. Additionally, this research suggests that mothers should be given opportunities to engage in some occupational activities that could give them resources to face the daily challenges of having a DS child in house.

TABLE 1.

Distribution of demographic characteristics among parents

\section{Referencias}

Abbeduto, L., Seltzer, M. M., Shattuck, P., Krauss, M. W., Orsmond, G., \& Murphy, M. M. (2004). Psychological well-being and coping in mothers of youths with autism, Down syndrome, or fragile X syndrome. American Journal of Mental Retardation : AJMR, 109(3), 237-254.

\begin{tabular}{|c|c|c|}
\hline \multirow{2}{*}{ Variable } & $\begin{array}{l}\text { Mothers } \\
\mathrm{n}(103)\end{array}$ & $\begin{array}{l}\text { Fathers } \\
\mathbf{n}(103)\end{array}$ \\
\hline & $\%$ & $\%$ \\
\hline Age in years (mean $\pm \mathrm{SD})$ & $46.07 \pm 0.74$ & $43.07 \pm 0.73$ \\
\hline \multicolumn{3}{|l|}{ Number of children } \\
\hline 1 & 13.59 & 12.62 \\
\hline 2 & 39.81 & 46.6 \\
\hline 3 & 31.07 & 28.16 \\
\hline $4+$ & 15.53 & 12.62 \\
\hline \multicolumn{3}{|l|}{ Occupational Status } \\
\hline Full-time employee $1 *$ & 30.10 & 89.32 \\
\hline Part-time employee & 16.50 & 5.83 \\
\hline Unemployed & 69.90 & 10.68 \\
\hline \multicolumn{3}{|l|}{ Marital status } \\
\hline Single & 6.8 & 3.88 \\
\hline Cohabitation & 37.86 & 40.78 \\
\hline Married & 48.54 & 51.46 \\
\hline Separated & 6.8 & 3.88 \\
\hline \multicolumn{3}{|l|}{ Education level } \\
\hline None & 6.8 & 3.88 \\
\hline Elementary school & 28.16 & 24.27 \\
\hline Secondary school & 22.33 & 33.01 \\
\hline Technical school & 14.56 & 8.74 \\
\hline College & 28.16 & 30.1 \\
\hline \multicolumn{3}{|c|}{ Weekly time spent with the child (in hours)* } \\
\hline $0-7$ & 0.97 & 12.67 \\
\hline $8-35$ & 19.42 & 55.32 \\
\hline $36-84$ & 43.69 & 27.18 \\
\hline $85-169$ & 35.92 & 4.85 \\
\hline
\end{tabular}

Note. ${ }^{*} \mathrm{p}<0.001$ comparing the distribution among mothers and fathers using a Chi-square test

Source: own work 


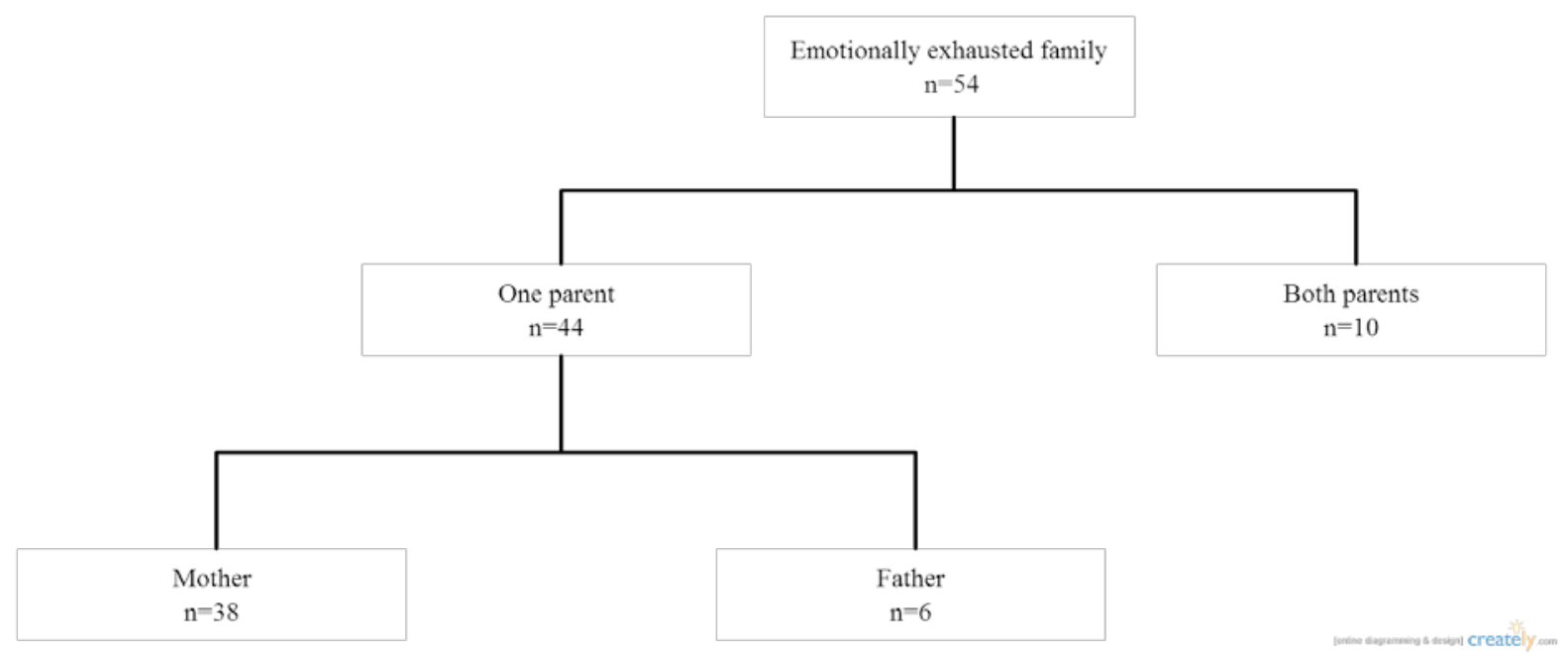

Figure 1. Distribution of emotional exhaustion among families and parents

Source: own work

Akgün, E. (2014). Annelerde stres ve tükenmisllik. International Journal of Human Sciences. / Uluslararast Insan Bilimleri Dergisi, 11(2), 238-250. doi: 10.14687/ijhs.v11i2.2786

Australian National Health and Medical Research Council. (1999). Guidelines for Ethical Review of Research Proposals for Human Somatic Cell Gene Therapy and Related Therapies. Canberra. Retrieved from https://www.nhmrc.gov.au/guidelinespublications/e38

Bull, M.J \& the Committee on Genetics. (2011). Health supervision for children with Down syndrome. Pediatrics, 128(2), 393-406. doi:10.1542/2011-1605

Cameron, S. J., Dobson, L. A., \& Day, D. M. (1991). Stress in parents of developmentally delayed and non-delayed preschool children. Canada's Mental Health, 39(1), 13-17. doi: 10.1007/s10803-012. 1604-y

Carver, C. S., Scheier, M. F., \& Weintraub, J. K. (1989). Assessing coping strategies: a theoretically based approach. Journal of Personality and Social Psychology, 56(2), 267-283.

Castilla, E. E., \& Orioli, I. M. (2004). ECLAMC: The Latin-American Collaborative Study of Congenital Malformations. Community Genetics, 7(2-3), 76-94. doi: 10.1159/000080776
Cuskelly, M., \& Gunn, P. (2006). Adjustment of children who have a sibling with Down syndrome: perspectives of mothers, fathers and children. Journal of Intellectual Disability Research: JIDR, 50(12), 917-925. doi: 10.1111/j.1365-2788.2006.00922.x

Dabrowska, A., \& Pisula, E. (2010). Parenting stress and coping styles in mothers and fathers of pre-school children with autism and Down syndrome. Journal of Intellectual Disability Research: JIDR, 54(3), 266-280.

Esdaile, S. A. (2009). Valuing difference: caregiving by mothers of children with disabilities. Occupational Therapy International, 16(2), 122-133. doi: 10.1002/oti.274

Gómez-Restrepo, C., Bohórquez, A., Pinto, D., Gil, J., Rondón, M., \& Díaz-Granados, N. (2004). Prevalencia de depresión y factores asociados con ella en la población colombiana. Revista Panamericana de Salud Pública, 16(6), 378-386.

Lachin, J. M. (2008). Sample size evaluation for a multiply matched case-control study using the score test from a conditional logistic (discrete Cox $\mathrm{PH}$ ) regression model. Statistics in Medicine, 27(14), 2509-2523.

Lam, L., \& Mackenzie, A. E. (2002). Coping with a child with Down syndrome: the experiences of mothers in Hong Kong. Qualitative Health Research, 12(2), 
223-237. Retrieved from http://www.ncbi.nlm.nih. gov/pubmed/11837372

Lenhard, W., Breitenbach, E., Ebert, H., SchindelhauerDeutscher, H. J., \& Henn, W. (2005). Psychological benefit of diagnostic certainty for mothers of children with disabilities: lessons from Down syndrome. American Journal of Medical Genetics. Part A, 133(2), 170-175.

Lindström, C., Aman, J., \& Norberg, A. L. (2011). Parental burnout in relation to sociodemographic, psychosocial and personality factors as well as disease duration and glycaemic control in children with Type 1 diabetes mellitus. Acta Paediatrica, 100(7), 1011-1017.

Martínez Fontanilles, A. M., \& Rodríguez Vernal, Y. (2010). Impacto familiar de una escuela para padres de niños con discapacidad. Medisan, 14(5), 18-623. Retrieved from http://bvs.sld.cu/revistas/ san/vol_14_5_10/san05510.pdf

Maslach, C., Jackson, S. E., \& Leiter, M. P. (1997). Maslach Burnout Inventory. In C. P. Zalaquett \& R. J. Wood (Eds.), Evaluating stress: A book of resources (pp. 191-218). Lanhan, MD: The Scarecrow Press.

McGrath, R. J., Stransky, M. L., Cooley, W. C., \& Moeschler, J. B. (2011). National profile of children with Down syndrome: disease burden, access to care, and family impact. The Journal of Pediatrics, 159(4), 535-540e2.

Molina, C. I. G., \& Agudelo, G. M. F. (2006). Calidad de vida de los cuidadores familiares. Aquichan, 6(1), 38-53. Retrieved from http://www.redalyc. org/resumen.oa?id=74160106

Most, D. E., Fidler, D. J., LaForce-Booth, C., LaforceBooth, C., \& Kelly, J. (2006). Stress trajectories in mothers of young children with Down syndrome. Journal of Intellectual Disability Research : JIDR, 50(7), 501-514.

Norberg, A. L. (2010). Parents of children surviving a brain tumor: burnout and the perceived diseaserelated influence on everyday life. Journal of Pediatric Hematology/oncology, 32(7), e285-e289. doi: 10.1097/MPH.0b013e3181e7dda6

Nurse, I. (1977). The functions and operation of workshops for mothers of young Down's syndrome children. SA Nursing Journal. SA Verplegingstydskrif,
44(11), 24-26. Retrieved from http://www.ncbi. nlm.nih.gov/pubmed/146264

Pelsma, D. M., Roland, B., Tollefson, N., \& Wigington, H. (1989). Parent Burnout: Validation of the Maslach Burnout Inventory with a Sample of Mothers. Measurement and Evaluation in Counseling and Development, 22(2), 81-87. Retrieved from http://eric.ed.gov/?id=EJ400097

Pérez, E. J. P., \& Baró, E. G. (2008). Síndrome de Down: Visión y perspectiva desde el contexto familiar en el círculo infantil especial. Revista Cubana de Medicina General Integral, 24(2), 1-10.

Pilling, S., Anderson, I., Goldberg, D., Meader, N., \& Taylor, C. (2009). Depression in adults, including those with a chronic physical health problem: summary of NICE guidance. BMJ (Clinical Research Ed.), 339, b4108. Retrieved from http://www. pubmedcentral.nih.gov/articlerender.fcgi?artid=3 $230232 \&$ tool $=$ pmcentre $\&$ rendertype $=$ abstract

Plieger, T., Melchers, M., Montag, C., Meermann, R., \& Reuter, M. (2015). Life stress as potential risk factor for depression and burnout. Burnout Research, 2(1), 19-24. doi: 10.1016/j.burn.2015.03.001

Procaccini, J., \& Kiefaber, M. (1983). Parent Burnout. Doubleday. Retrieved from http://books. google.com.co/books/about/Parent_Burnout. html?id=PglFAAAAYAAJ\&pgis $=1$

Ryde-Brandt, B. (1988). Mothers of primary school children with Down's syndrome. How do they experience their situation? Acta Psychiatrica Scandinavica, 78(1), 102-108. Retrieved from http://www. ncbi.nlm.nih.gov/pubmed/2972164

Sharav, T., Collins, R., \& Shlomo, L. (1985). Effect of maternal education on prognosis of development in children with Down syndrome. Pediatrics, 76(3), 387-391. Retrieved from http://www.ncbi.nlm.nih. gov/pubmed/3162149

StataCorp. (2011). Stata Statistical Software: Release 12. College Station, TX: StataCorp LP.

van der Veek, S. M. C., Kraaij, V., \& Garnefski, N. (2009). Cognitive coping strategies and stress in parents of children with Down syndrome: a prospective study. Intellectual and Developmental Disabilities, 47(4), 295-306. http://doi. org/10.1352/1934-9556-47.4.295 
Varghese, R. T., \& Venkatesan, S. (2013). A Comparative Study of Maternal Burnout in Autism and Hearing Impairment. International Journal of Psychology and Psychiatry, 1(2), 101-108. doi: 10.5958/j.2320-6233.1.2.016

Whooley, M. A., Avins, A. L., Miranda, J., \& Browner, W. S. (1997). Case-finding instruments for depression. Two questions are as good as many. Journal of General Internal Medicine, 12(7), 439-445. doi: 10.1046/j.1525-1497.1997.00076.x

Zarante, I., Franco, L., López, C., \& Fernández, N. (2010). Frecuencia de malformaciones congénitas: evaluación y pronóstico de 52.744 nacimientos en tres ciudades colombianas. Biomédica, 30(1), 65-71. doi: 10.7705/biomedica.v30i1.154 
